\title{
Virulence of Puccinia triticina, the Wheat Leaf Rust Fungus, in the United States in 2017
}

\author{
J. A Kolmer \\ USDA-ARS Cereal Disease Laboratory, St. Paul, MN 55108
}

\begin{abstract}
Samples of wheat leaves infected with the leaf rust fungus, Puccinia triticina, were obtained in 2017 from agricultural experiment station plots, demonstration plots, and farm fields in the Great Plains, the Ohio Valley, the southeastern states, California, and Washington in order to determine the prevalent virulence phenotypes present in the United States. A total of 65 virulence phenotypes were identified among the 469 single uredinial isolates that were tested on 20 near-isogenic lines of Thatcher wheat that differ for leaf rust resistance genes. Virulence phenotypes MBTNB at $11.3 \%$ of the overall population, and MCTNB at 7.0\%, were the first and third most common phenotypes. Both phenotypes were found mostly in the southeast-

Virulence to leaf rust resistance gene Lr39, which is present in hard red winter wheat cultivars, was highest in the Great Plains region. Virulence to $\mathrm{Lrll}$ and $\mathrm{Lrl8}$, which are present in soft red winter wheat cultivars, was highest in the southeastern states and Ohio Valley region. Virulence to $L r 21$, which is present in hard red spring wheat cultivars, was highest in the northern Great Plains region. The predominate $P$. triticina phenotypes from the soft red winter wheat regions of the southeastern states and Ohio Valley area differed from those in the hard red winter and hard red spring wheat areas of the Great Plains region. Collections from Washington had unique virulence phenotypes that had not been previously detected.
\end{abstract} ern states and Ohio Valley region. Phenotype TFTSB at $10.9 \%$ was the second most common phenotype and was found mostly in southern Texas.
Keywords: fungi, wheat, pathogen diversity
Leaf rust of wheat, caused by Puccinia triticina Eriks., is a common disease of wheat in the United States (Kolmer et al. 2007a) and worldwide. The leaf rust fungus is widely distributed across nonarid wheat producing regions of the world, where the crop matures in warm to hot weather (Roelfs et al. 1992). The initial leaf rust infections in the United States are usually found on winter wheat in January-February in Texas, along the southern Gulf Coast, and the Atlantic seaboard. In the spring, leaf rust infections are spread by the wind dissemination of urediniospores to regions further north. In the United States, leaf rust on wheat is most prevalent in the southeastern states, the Ohio Valley, and the Great Plains region.

Leaf rust resistance is an important goal for wheat breeding programs in the United States and worldwide (Kolmer et al. 2009). Since the 1940s, numerous leaf rust resistance genes have been added to wheat germplasm and cultivars in the United States (Browder 1973, 1980; McVey and Long 1993). Hard red winter cultivars grown in the southern to mid-Great Plains region have combinations of seedling resistance genes $L r 1, L r 3 a, L r 10, \operatorname{Lr} 14 a, \operatorname{Lr} 16, \operatorname{Lr} 21$, Lr24, Lr26, Lr37, and Lr39 (J. Kolmer, unpublished data) that give resistance to specific phenotypes of $P$. triticina. In addition, some of these cultivars also have the adult plant resistance genes $\operatorname{Lr} 12$ and Lr34. The soft red winter wheat cultivars grown in the southeastern states and the Ohio Valley have had combinations of genes $L r l$, Lr2a, Lr9, Lr10, Lr11, Lr12, Lr14a, Lr18, Lr26, and Lr37 (Kolmer 2003, 2010). Hard red spring wheat cultivars grown in South Dakota, Minnesota, and North Dakota have combinations of Lr2a, Lr10,

Corresponding author: J. A. Kolmer; jim.kolmer@ars.usda.gov

The author(s) declare no conflict of interest.

Accepted for publication 26 February 2019.

This article is in the public domain and not copyrightable. It may be freely reprinted with customary crediting of the source. The American Phytopathological Society, 2019.
Lr13, Lr16, Lr21, Lr23, and Lr34 (Oelke and Kolmer 2004, 2005). However, phenotypes of $P$. triticina that have virulence to each of the phenotype specific seedling resistance genes have been identified in the United States. The widespread use of a wheat cultivar with an effective leaf rust resistance gene places selection pressure on the $P$. triticina population for increased virulence. In 1994, the cultivar 'Jagger' with $\operatorname{Lr37}$ (Xue et al. 2018) was released in the southern Great Plains region and was highly resistant to leaf rust in the first 2 years. However, by 1996 isolates of $P$. triticina that had virulence to $\operatorname{Lr} 37$ were widespread in both the United States and Canada (Kolmer 1998; Long et al. 2000) due to selection by 'Jagger'. Similarly, the winter wheat cultivar 'Overley' with Lr39 released in 2003 (Kolmer et al. 2007b), and spring wheats with Lr21 (Kolmer and Anderson 2011) released in the mid-2000s have selected phenotypes of $P$. triticina with high virulence to both of these genes. As a result of host selection, phenotypes of $P$. triticina virulent to effective leaf rust resistance genes can increase to high frequency within a few years, which has resulted in a constant turnover of the predominant virulence phenotypes of $P$. triticina in the United States.

In the United States, annual surveys of virulence phenotypes of $P$. triticina have been conducted since 1926 (Mains and Jackson 1926). From 1926 to 1946, leaf rust collections from the eastern United States were processed by the USDA at Purdue University in West Lafayette, IN, and collections from the western United States were processed by the USDA at Kansas State University in Manhattan, KS. After 1946, the survey for all of the United States was done at Manhattan, KS. Results of the virulence surveys from 1951 to 1959 were published yearly in the Plant Disease Reporter. A summary of the results from the surveys from 1926 to 1960 (Johnston et al. 1968) was published as a USDA technical bulletin. Starting in 1960, the survey results were published in Crops Research, a USDA publication (Browder et al. 1965). Since 1978 (Long et al. 1985), the USDA-ARS Cereal Disease Laboratory in St. Paul, MN has conducted the $P$. triticina virulence survey, and the results have been published annually in Plant Disease. The objectives of the surveys have been to determine the prevalence and distribution of $P$. triticina virulence phenotypes across the United States and to determine 
if new phenotypes are increasing in response to wheat cultivars with effective leaf rust resistance genes. Results from these surveys are a valuable resource for development of leaf rust resistant wheat cultivars and for population biology studies of $P$. triticina. The $P$. triticina population in the United States is unique compared with most other countries since the host population is composed of different classes of wheat that differ for leaf rust resistance genes. This has resulted in regional populations that differ for predominant virulence phenotypes, although there is also migration of phenotypes between the regions. Distinct groups of $P$. triticina based on molecular genotypes were described using isolates from the surveys (Ordoñez and Kolmer 2009). Isolates from the survey with different combinations of virulence are used to postulate the identity of seedling leaf rust resistance genes in wheat cultivars (Oelke and Kolmer 2004), and to identify wheat germplasm lines that have effective resistance to the current $P$. triticina population. In 2017, collections of $P$. triticina from different wheat growing regions in the United States were tested for virulence phenotype, and the results were compared with data from previous surveys (Kolmer and Hughes 2018).

\section{Materials and Methods}

In 2017, USDA-ARS personnel and cooperators in the United States made collections of leaf rust from wheat plots and fields in surveys of the Great Plains, Ohio River Valley, southeastern states, California, and Washington. The initial collection trip was in March in the Rio Grande Valley of Texas, and the last trip was in late July in northern Minnesota and North Dakota. Most of the collections came from wheat cultivars and breeding lines in state agricultural experiment station plots, and additional collections were made in wheat cultivar demonstration plots and farm fields. Collections consisted of one to several leaves with uredinia of $P$. triticina from a single cultivar or breeding line. The leaves were placed in glassine or paper envelopes, dried at room temperature for $24 \mathrm{~h}$, and then stored at $4^{\circ} \mathrm{C}$ until processed for virulence phenotype identification. Collections were not made from nurseries inoculated for rust resistance evaluation.

Identification of virulence phenotypes. Urediniospores from each sample were vacuum collected into 00 size gelatin capsules, which were then filled with $0.25 \mathrm{ml}$ of Soltrol 170 oil. The oil-spore suspension was then sprayed onto 7-day-old seedling plants of the wheat cultivar 'Little Club', which had been treated with a $30-\mathrm{ml}$ solution ( $1 \mathrm{~g}$ dissolved in 3 liters of $\mathrm{H}_{2} \mathrm{O}$ ) of maleic hydrazide at coleoptile emergence, in order to enhance spore production. The inoculated 'Little Club' seedlings were incubated at room temperature in a mist chamber overnight, and then placed in Plexiglas isolation chambers in a greenhouse at $20-24^{\circ} \mathrm{C}$. After $12-15$ days, when

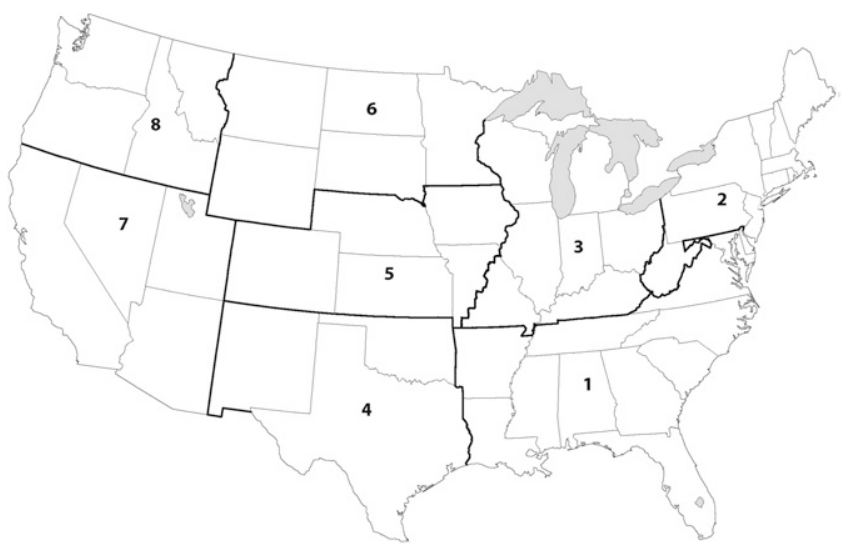

Fig. 1. Agroecological areas for Puccinia triticina in the United States. Area 1, mainly southern-adapted soft red winter wheat; Areas 2 and 3, mostly northern-adapted soft red and soft white winter wheat; Area 4 , mixed wheat types but primarily hard red winter; Area 5, hard red winter wheat; Area 6, mixed wheat types but primarily hard red spring and durum; Area 7, spring wheat planted in late fall; and Area 8, mixed wheat types but primarily soft white winter. uredinia had appeared, the leaves were trimmed, leaving 3-4 leaves, each with single uredinia. After 9-14 days, when secondary uredinia began to form around the initial infection, urediniospores from a single uredinia were collected into a 00 size gel capsule with a cyclone spore collector. Spores from 2-3 single uredinia were collected separately from each $P$. triticina sample. Host differential sets of 20 near-isogenic Thatcher lines with resistance genes $L r 1, L r 2 a, L r 2 c$, Lr3, Lr3ka, Lr9, Lr10, Lr11, Lr14a, Lr16, Lr17, Lr18, Lr21, Lr24, $L r 26, L r 28, L r 30, L r 39, L r 42$, and $L r B$ were inoculated with the single-uredinial isolates. Inoculation, incubation, and greenhouse conditions for the differential sets were the same as described above. Spores from some single-uredinial isolates were increased for one generation on 'Little Club' in order to have a sufficient amount of spores to inoculate the differential sets. Avirulent or virulent infection types (IT) to each individual differential were described with a five-letter code based on the original three-letter code proposed for P. triticina (Long and Kolmer 1989). Each letter corresponds to the avirulent or virulent response of four differentials. The Thatcher lines with genes $L r 1, L r 2 a, L r 2 c$, and $L r 3 a$ were the first set of differentials; lines with genes $L r 9, L r 16, L r 24$, and $\operatorname{Lr} 26$ were the second set; lines with genes $L r 3 k a, L r 11, L r 17$, and $L r 30$ were the third set; lines with $\operatorname{LrB}, \operatorname{LrlO}, \operatorname{Lrl} 4 a$, and $\operatorname{Lr} 18$ were the fourth set; and lines with $L r 21, L r 28, L r 39$, and $L r 42$ were the fifth set. Infection types of 0 (immune response with no sign of infection) to $2^{+}$(moderate size uredinia with prominent chlorosis) were considered as avirulent, and IT of 3 (moderate size uredinia) to 4 (large uredinia) were considered as virulent. Isolates with unique virulence phenotypes were tested a second time to confirm their virulence.

The frequency of virulence phenotypes and virulence to individual leaf rust resistance genes were determined for $P$. triticina collections from agroecological-geographic areas 1, 2, 3, 4, 5, 6, 7, and 8 in 2017 (Fig. 1). A modified Nei's genetic distance was used to calculate the virulence distance between isolates in areas $1,3,4,5,6$, and 8 with NTSYS-pc v.2.2 (Exeter Software, Seatauket, NY). Virulence distance between isolates in the different areas was shown with UPGMA clustering.

The leaf rust resistance genes in current soft red winter wheat, hard red winter wheat, and hard red spring wheat cultivars were postulated on the basis of IT to a set of 10-12 P. triticina virulence phenotypes that varied for virulence to the most important resistance genes. The gene postulations were made using previously cited methods (Kolmer 2003; Oelke and Kolmer 2004). Information on wheat cultivars grown in individual states for 2017 was obtained from the USDA-National Agricultural Statistical Service website (https://www.nass.usda.gov). Information on temperature and moisture conditions for 2017 was obtained from the National Oceanic and Atmospheric Administration website (https://www.noaa.gov).

\section{Results}

Leaf rust occurrence and isolate collections. From December of 2016 to February of 2017, the eastern, southern, Ohio Valley, Midwest, and Great Plains regions of the United States had higher than average temperatures (NOAA 2018). The average winter temperature across the continental United States was $2.05^{\circ} \mathrm{C}$ above the twentieth century average. Precipitation varied across the regions during the winter months from much above average to much below average. The warm conditions during the winter months with abundant moisture in some regions allowed stripe rust of wheat, caused by Puccinia striiformis f. sp. tritici, to become well established and spread throughout the southern Great Plains and southeastern states. Because infections of $P$. triticina develop, increase, and spread later in the spring at warmer temperatures compared with stripe rust, the high level of stripe infections reduced the amount of wheat leaf tissue available for infection, thus reducing the overall spread and severity of $P$. triticina throughout the United States. Many hard red winter wheat cultivars in the Great Plains and soft red winter wheat cultivars in the southeastern states were sprayed with fungicide to reduce the amount of damage caused by stripe rust. Fungicide application also reduced the spread of leaf rust across these regions and in the northern Great Plains. The warm temperatures continued into the spring, 
as the continental United States had higher than average temperatures from March to May at $1.4^{\circ} \mathrm{C}$ above the average. Parts of the Midwest, mid-Atlantic states, and Great Plains states had much above average precipitation in the spring, while the southern states had normal to above average precipitation, and the northern Great Plains states were drier than normal. As a result of weather conditions that favored stripe rust development and spread, leaf rust infections were at low levels throughout the United States in 2017, although isolated regions with high severity were noted.

Leaf rust was first noted in southern Texas in February, and was at high levels in wheat breeding plots in south-central Texas by early April. In Oklahoma, leaf rust was at low levels in late March and increased to higher levels by mid-April. In late April, leaf rust was the predominant disease on wheat throughout Oklahoma and was severe in the central part of the state. Leaf rust was present in south-central Kansas at low incidence and severity in the first week of April, and was present in central, north-central, and west-central parts of the state by early May. Leaf rust was at high levels in fields of wheat that had not been treated with fungicide in south-central and eastern Nebraska in early June. Leaf rust was present in South Dakota, Minnesota, and North Dakota in mid-June and increased to moderate severity levels on susceptible wheat cultivars in breeding plots by the end of July.

Leaf rust was present in the Gulf Coast region in January in Mississippi, Louisiana, Alabama, and Georgia. In the mid-Atlantic region, leaf rust was widespread and severe in eastern Virginia during the second week of May. Leaf rust was present throughout the Ohio Valley states, with the first observation in mid-June in central Missouri and southern Illinois. In most of this region, leaf rust was the most prevalent disease of wheat. Leaf rust was present in low incidence and severity in the Palouse region of eastern Washington State, and the adjacent region of Idaho in early July. Leaf rust was also present in western Washington in experimental wheat plots. Losses were minimal throughout the United States, however 10\% yield loss in wheat due to leaf rust was estimated in Oklahoma. A complete summary of the wheat leaf rust incidence and severity in 2017 in the United States can be found at the USDA-ARS Cereal Disease Laboratory website (https://www.ars.usda.gov/arsuserfiles/50620500/ CRBs/2017_September_FinalCRB-final.pdf). A total of 209 collections of leaf rust were obtained from 22 states in areas 1, 2, 3, 4, 5, 6, 7 , and 8 .

Distribution of virulence phenotypes. In 2017, a total of 65 virulence phenotypes were identified from a total of 469 singleuredinial isolates of $P$. triticina that were tested on Thatcher lines with single genes for leaf rust resistance (Table 1). Phenotypes MBTNB at $11.3 \%$, TFTSB at $10.9 \%$, and MCTNB at $7.0 \%$ were the three most common phenotypes across the United States. MBTNB and MCTNB were mostly found in the southeastern states of area 1 and the Ohio Valley states of area 3. Phenotype TFTSB was mostly found in the Rio Grande river valley in the hard red winter region of area 4 . No phenotype was found in all areas. In the southeastern states of area 1, a total of 25 virulence phenotypes were identified from 120 isolates, with MBTNB (27.5\%), MCTNB (20\%), and TBRKG (5.8\%) the most prevalent. In New York State (area 2), all three isolates tested had phenotype PBDGG. In the Ohio Valley states of area 3, there were 13 phenotypes identified from 38 isolates, with MBTNB (44.7\%), MCTNB (18.4\%), and TFTSB (7.9\%) the most common. In Texas and Oklahoma (area 4), 24 phenotypes were identified from 117 isolates, with TFTSB (36.7\%), MPPSD (13.7\%), and MNPSD (7.7\%) the most common phenotypes. In Kansas and Nebraska (area 5), 14 phenotypes were identified from 40 isolates, with MBDSD (17.5\%), MNPSD (15\%), and TNBGJ (12.5\%) the most common. In South Dakota, Minnesota, and North Dakota (area 6), there were 30 phenotypes identified from 127 isolates, with TNBJJ (15.7\%), TBBGS (13.4\%), MPPSD (9.4\%), and TNBGJ (9.4\%) the most common phenotypes. In California (area 7), the two isolates that were tested were phenotypes MBSBD and MCSBD. In Washington State (area 8), there were five phenotypes identified from 22 isolates, with LBDSG (45.5\%), MCDSG (27.3\%), and LCDSG (13.65) the most common phenotypes.
Virulence frequencies. Across the United States, the frequency of virulence to leaf rust resistance genes varied among the different areas (Table 2). Virulence to $\operatorname{Lr} 9, \operatorname{Lr} 24$, and $\operatorname{Lr} 39$ were highest in areas 4, 5, and 6; virulence to $L r 26$ was common in all areas except for area 2; virulence to $\operatorname{Lr} 11$ and $L r 18$ were highest in areas 1 and 3. Isolates with virulence to $\mathrm{Lrll}$ were common in all regions, and virulence to $L r 21$ was present only in areas 4, 5, and 6. Virulence to $L r 3$ was at $100 \%$ in all areas, except for area 1 at $99.2 \%$ and Washington State (area 8) at $40.9 \%$. Virulence to $L r l$ was at $100 \%$ in all areas, and virulence to $L r 42$ was not present in any area in 2017 . Virulence to the other $L r$ genes also varied across the different areas. The areas split into three groups based on Nei's genetic distance measure adapted for virulence (Fig. 2). Isolates in areas 1 and 3 were highly related, as were isolates in areas 4, 5, and 6. Isolates in area 8 were dissimilar for virulence compared with all other areas. In area 1, isolates with virulence to $\operatorname{Lrll}$ and $\operatorname{Lrl} 8$ decreased in frequency from 2016, and isolates with virulence to $L r 9$ and $L r 26$ increased (Fig. 3). In area 4 , the frequency of isolates with virulence to $\operatorname{Lr} 39$ decreased from 2016, and isolates with virulence to $L r 17, L r 24$, and $L r 26$ increased. In area 6, the frequency of isolates with virulence to $L r 16$ and $L r 21$ decreased from 2016, and isolates with virulence to $L r 2 a$ and $L r 24$ increased.

\section{Discussion}

The virulence in the U.S. P. triticina population in 2017 was highly associated with the leaf rust resistance genes present in the different market classes of wheat in the United States. In the hard red winter wheat region of areas 4,5 , and 6 , over $50 \%$ of the isolates had virulence to Lr39. Five (T158, Winterhawk, WB Grainfield, TAM 111, TAM 112) of the 10 most widely grown wheat cultivars in Kansas in 2017, three (TAM 111, TAM 112, Greer) of the 10 most widely grown cultivars in Texas, and three (Ruby Lee, Fuller, Winterhawk) of the 10 most widely grown cultivars in Oklahoma were postulated to have Lr39 (NASS 2018). The second and third most common phenotypes in Texas and Oklahoma (area 4), MNPSD and MPPSD, and the three most common phenotypes MBDSD, MNPSD, and TNBGJ in Kansas and Nebraska (area 5) had virulence to $L r 39$. The widespread planting of cultivars with Lr39 has continued to select phenotypes of $P$. triticina with Lr39 virulence. Many of the phenotypes with virulence to Lr39, such as TNBJJ and TNBGJ, are also virulent to $\operatorname{Lr} 9$ and $\operatorname{Lr} 24$, which has maintained the virulence to these genes at high levels in areas 4,5 , and 6.

A high proportion of cultivars grown in areas 4 and 5 also have Lr37 (McIntosh et al. 1995), based on the presence of the 2NS translocation from Aegilops ventricosa (Cruz et al. 2016). Most phenotypes of $P$. triticina with virulence to $L r 17$ in the United States are also virulent to $L r 37$ (Kolmer 2017; Kolmer et al. 2005). Phenotypes with virulence to $\operatorname{Lr} 17$ are now widespread across areas $1,3,4,5$, and 6, likely due to selection of phenotypes for virulence to Lr37. In previous years, 'Jagger' and many cultivars derived from 'Jagger' were postulated to have $\mathrm{Lr} 17 \mathrm{a}$ based on seedling infection types to different $P$. triticina phenotypes. However, it was later shown (Kolmer 2017) that 'Santa Fe', which was directly derived from 'Jagger', actually had Lr37 and not Lr17a. There may be some allelic relationship between $\operatorname{Lr} 17$ and $\operatorname{Lr} 37$, as these genes are in the same region on chromosome $2 \mathrm{AS}$ in wheat (Xue et al. 2018). The same avirulence gene in $P$. triticina may recognize both $L r 17$ and $L r 37$, as found in for avirulence to $L r 2 a$ and $L r 2 c$ (Dyck and Samborski 1974).

In 2017, the most common phenotype collected in Texas and Oklahoma was TFTSB. Most of the collections of this phenotype came from winter wheat sentinel plots in the Rio Grande Valley of Texas that were composed of cultivars with $\mathrm{Lr} 26 / \mathrm{Sr} 31$ on the 1B/ $1 \mathrm{RS}$ translocation in wheat (McIntosh et al. 1995). TFTSB is virulent to $L r 26$, which accounts for the high frequency of this phenotype.

In the northern hard red spring wheat region of Minnesota, South Dakota, and North Dakota (area 6), the second most common phenotype, TBBGS, had avirulence to both $L r 21$ and $L r 39$. In Minnesota and North Dakota in 2017, cultivars with Lr21 (Barlow, Elgin-ND, Glenn, Prosper, Faller, Shelley, and TCG Spitfire) were widely 
Table 1. Number and frequency (\%) of virulence phenotypes of Puccinia triticina in the United States in 2017 identified by virulence to $20^{\mathrm{a}}$ lines of Thatcher wheat with single genes for leaf rust resistance

\begin{tabular}{|c|c|c|c|c|c|c|c|c|c|c|c|c|c|c|c|c|c|c|}
\hline \multirow{2}{*}{$\begin{array}{l}\text { Phenotype } \\
\text { virulence }\end{array}$} & \multicolumn{2}{|c|}{ Area $1^{b}$} & \multicolumn{2}{|c|}{ Area $2^{c}$} & \multicolumn{2}{|c|}{ Area $3^{\text {d }}$} & \multicolumn{2}{|c|}{ Area $4^{\mathbf{e}}$} & \multicolumn{2}{|c|}{ Area $5^{f}$} & \multicolumn{2}{|c|}{ Area $6^{\mathrm{g}}$} & \multicolumn{2}{|c|}{ Area $7^{h}$} & \multicolumn{2}{|c|}{ Area $8^{i}$} & \multicolumn{2}{|c|}{ Total } \\
\hline & $\#$ & $\%$ & $\#$ & $\%$ & $\#$ & $\%$ & $\#$ & $\%$ & $\#$ & $\%$ & $\#$ & $\%$ & $\#$ & $\%$ & $\#$ & $\%$ & $\#$ & $\%$ \\
\hline $\begin{array}{l}\text { LBDSG } \\
1,17, \mathrm{~B}, 10,14 \mathrm{a}, 28\end{array}$ & 0 & 0 & 0 & 0 & 0 & 0 & 0 & 0 & 0 & 0 & 0 & 0 & 0 & 0 & 10 & 45.5 & 10 & 2.1 \\
\hline $\begin{array}{l}\text { LCDSG } \\
1,26,17, \mathrm{~B}, 10,14 \mathrm{a}, 28\end{array}$ & 1 & 0.8 & 0 & 0 & 0 & 0 & 0 & 0 & 0 & 0 & 0 & 0 & 0 & 0 & 3 & 13.6 & 4 & 0.9 \\
\hline $\begin{array}{l}\text { MBDSB } \\
1,3,17, \mathrm{~B}, 10,14 \mathrm{a}\end{array}$ & 0 & 0 & 0 & 0 & 3 & 2.6 & 0 & 0 & 0 & 0 & 0 & 0 & 0 & 0 & 0 & 0 & 3 & 0.6 \\
\hline $\begin{array}{l}\text { MBDSD } \\
1,3,17, \mathrm{~B}, 10,14 \mathrm{a}, 39\end{array}$ & 6 & 5 & 0 & 0 & 0 & 0 & 5 & 4.3 & 7 & 17.5 & 7 & 5.5 & 1 & 50 & 0 & 0 & 26 & 5.5 \\
\hline $\begin{array}{l}\text { MBDSG } \\
1,3,17, \mathrm{~B}, 10,14 \mathrm{a}, 28\end{array}$ & 0 & 0 & 0 & 0 & 0 & 0 & 0 & 0 & 0 & 0 & 0 & 0 & 0 & 0 & 2 & 9.1 & 2 & 0.4 \\
\hline $\begin{array}{l}\text { MBPSB } \\
1,3,3 \mathrm{ka}, 17,30, \mathrm{~B}, 10,14 \mathrm{a}\end{array}$ & 0 & 0 & 0 & 0 & 0 & 0 & 4 & 3.4 & 0 & 0 & 0 & 0 & 0 & 0 & 0 & 0 & 4 & 0.9 \\
\hline $\begin{array}{l}\text { MBPSD } \\
1,3,3 \mathrm{ka}, 17,30, \mathrm{~B}, 10,14 \mathrm{a}, 39\end{array}$ & 2 & 1.7 & 0 & 0 & 0 & 0 & 4 & 3.4 & 0 & 0 & 2 & 1.6 & 0 & 0 & 0 & 0 & 8 & 1.7 \\
\hline $\begin{array}{l}\text { MBTNB } \\
1,3,3 \mathrm{ka}, 11,17,30, \mathrm{~B}, 14 \mathrm{a}\end{array}$ & 33 & 27.5 & 0 & 0 & 17 & 44.7 & 0 & 0 & 1 & 2.5 & 2 & 1.6 & 0 & 0 & 0 & 0 & 53 & 11.3 \\
\hline $\begin{array}{l}\text { MCDSB } \\
1,3,26,17, \mathrm{~B}, 10,14 \mathrm{a}\end{array}$ & 0 & 0 & 0 & 0 & 0 & 0 & 1 & 0.9 & 0 & 0 & 0 & 0 & 0 & 0 & 0 & 0 & 1 & 0.2 \\
\hline $\begin{array}{l}\text { MCDSD } \\
1,3,26,17, \mathrm{~B}, 10,14 \mathrm{a}, 39\end{array}$ & 0 & 0 & 0 & 0 & 0 & 0 & 0 & 0 & 0 & 0 & 0 & 0 & 1 & 50 & 0 & 0 & 1 & 0.2 \\
\hline $\begin{array}{l}\text { MCDSG } \\
1,3,26,17, B, 10,14 a, 28\end{array}$ & 0 & 0 & 0 & 0 & 0 & 0 & 0 & 0 & 0 & 0 & 3 & 2.4 & 0 & 0 & 6 & 27.3 & 9 & 1.9 \\
\hline $\begin{array}{l}\text { MCPSB } \\
1,3,26,3 \mathrm{ka}, 17,30, \mathrm{~B}, 10,14 \mathrm{a}\end{array}$ & 0 & 0 & 0 & 0 & 0 & 0 & 2 & 1.7 & 0 & 0 & 0 & 0 & 0 & 0 & 0 & 0 & 2 & 0.4 \\
\hline $\begin{array}{l}\text { MCPSD } \\
1,3,26,3 \mathrm{ka}, 17,30, \mathrm{~B}, 10,14 \mathrm{a}, 39\end{array}$ & 0 & 0 & 0 & 0 & 0 & 0 & 1 & 0.9 & 0 & 0 & 2 & 1.6 & 0 & 0 & 0 & 0 & 3 & 0.6 \\
\hline $\begin{array}{l}\text { MCTNB } \\
1,3,26,3 \mathrm{ka}, 11,17,30, \mathrm{~B}, 14 \mathrm{a}\end{array}$ & 24 & 20 & 0 & 0 & 7 & 18.4 & 0 & 0 & 2 & 5 & 0 & 0 & 0 & 0 & 0 & 0 & 33 & 7.0 \\
\hline $\begin{array}{l}\text { MDBBG } \\
1,3,24,28\end{array}$ & 0 & 0 & 0 & 0 & 0 & 0 & 1 & 0.9 & 0 & 0 & 0 & 0 & 0 & 0 & 0 & 0 & 1 & 0.2 \\
\hline $\begin{array}{l}\text { MDPSD } \\
1,3,24,3 \mathrm{ka}, 17,30, \mathrm{~B}, 10,14 \mathrm{a}, 39\end{array}$ & 4 & 3.3 & 0 & 0 & 0 & 0 & 0 & 0 & 0 & 0 & 2 & 1.6 & 0 & 0 & 0 & 0 & 6 & 1.3 \\
\hline $\begin{array}{l}\text { MFGJG } \\
1,3,24,26,11,10,14 \mathrm{a}, 28\end{array}$ & 4 & 3.3 & 0 & 0 & 0 & 0 & 0 & 0 & 0 & 0 & 1 & 0.8 & 0 & 0 & 0 & 0 & 5 & 1.1 \\
\hline $\begin{array}{l}\text { MFGJJ } \\
1,3,24,26,11,10,14 a, 28,39\end{array}$ & 0 & 0 & 0 & 0 & 0 & 0 & 0 & 0 & 1 & 2.5 & 0 & 0 & 0 & 0 & 0 & 0 & 1 & 0.2 \\
\hline $\begin{array}{l}\text { MFGKG } \\
1,3,24,26,11,10,14 \mathrm{a}, 18,28\end{array}$ & 1 & 0.8 & 0 & 0 & 0 & 0 & 0 & 0 & 0 & 0 & 0 & 0 & 0 & 0 & 0 & 0 & 1 & 0.2 \\
\hline $\begin{array}{l}\text { MFJSB } \\
1,3,24,26,11,17, \mathrm{~B}, 10,14 \mathrm{a}\end{array}$ & 0 & 0 & 0 & 0 & 0 & 0 & 0 & 0 & 0 & 0 & 1 & 0.8 & 0 & 0 & 0 & 0 & 1 & 0.2 \\
\hline $\begin{array}{l}\text { MFPSB } \\
1,3,24,26,3 \mathrm{ka}, 17,30, \mathrm{~B}, 10,14 \mathrm{a}\end{array}$ & 1 & 0.8 & 0 & 0 & 0 & 0 & 0 & 0 & 0 & 0 & 1 & 0.8 & 0 & 0 & 0 & 0 & 2 & 0.4 \\
\hline $\begin{array}{l}\text { MFPSD } \\
1,3,24,26,3 \mathrm{ka}, 17,30, \mathrm{~B}, 10,14 \mathrm{a}, 39\end{array}$ & 0 & 0 & 0 & 0 & 1 & 2.6 & 2 & 1.7 & 1 & 2.5 & 0 & 0 & 0 & 0 & 0 & 0 & 4 & 0.9 \\
\hline $\begin{array}{l}\text { MFTSB } \\
1,3,24,26,3 \mathrm{ka}, 11,17,30, \mathrm{~B}, 10,14 \mathrm{a}\end{array}$ & 0 & 0 & 0 & 0 & 0 & 0 & 0 & 0 & 0 & 0 & 0 & 2 & 1.6 & 0 & 0 & 0 & 2 & 0.4 \\
\hline $\begin{array}{l}\text { MGPSB } \\
1,3,16,3 \mathrm{ka}, 17,30, \mathrm{~B}, 10,14 \mathrm{a}\end{array}$ & 0 & 0 & 0 & 0 & 0 & 0 & 0 & 0 & 0 & 0 & 0 & 1 & 0.8 & 0 & 0 & 0 & 1 & 0.2 \\
\hline $\begin{array}{l}\text { MLPSD } \\
1,3,9,3 \mathrm{ka}, 17,30, \mathrm{~B}, 10,14 \mathrm{a}, 39\end{array}$ & 3 & 2.5 & 0 & 0 & 0 & 0 & 1 & 0.9 & 3 & 7.5 & 2 & 1.6 & 0 & 0 & 0 & 0 & 9 & 1.9 \\
\hline $\begin{array}{l}\text { MMDSD } \\
1,3,9,26,17, \mathrm{~B}, 10,14 \mathrm{a}, 39\end{array}$ & 0 & 0 & 0 & 0 & 0 & 0 & 1 & 0.9 & 0 & 0 & 0 & 0 & 0 & 0 & 0 & 0 & 1 & 0.2 \\
\hline $\begin{array}{l}\text { MMNSD } \\
1,3,9,26,3 \mathrm{ka}, 17, \mathrm{~B}, 10,14 \mathrm{a}, 39\end{array}$ & 1 & 0.8 & 0 & 0 & 0 & 0 & 0 & 0 & 0 & 0 & 0 & 0 & 0 & 0 & 0 & 0 & 1 & 0.2 \\
\hline $\begin{array}{l}\text { MMPSD } \\
1,3,9,26,3 \mathrm{ka}, 17,30, \mathrm{~B}, 10,14 \mathrm{a}, 39\end{array}$ & 1 & 0.8 & 0 & 0 & 0 & 0 & 1 & 0.9 & 0 & 0 & 1 & 0.8 & 0 & 0 & 0 & 0 & 3 & 0.6 \\
\hline $\begin{array}{l}\text { MNPSD } \\
1,3,9,24,3 \mathrm{ka}, 17,30, \mathrm{~B}, 10,14 \mathrm{a}, 39\end{array}$ & 5 & 4.2 & 0 & 0 & 0 & 0 & 9 & 7.7 & 6 & 15 & 10 & 7.9 & 0 & 0 & 0 & 0 & 30 & 6.4 \\
\hline $\begin{array}{l}\text { MPDSD } \\
1,3,9,24,26,17, \mathrm{~B}, 10,14 \mathrm{a}, 39\end{array}$ & 0 & 0 & 0 & 0 & 0 & 0 & 1 & 0.9 & 0 & 0 & 0 & 0 & 0 & 0 & 0 & 0 & 1 & 0.2 \\
\hline $\begin{array}{l}\text { MPPSD } \\
1,3,9,24,26,3 \mathrm{ka}, 17,30, \mathrm{~B}, 10,14 \mathrm{a}, 39\end{array}$ & 3 & 2.5 & 0 & 0 & 1 & 2.6 & 16 & 13.7 & 5 & 12.5 & 12 & 9.4 & 0 & 0 & 0 & 0 & 37 & 7.9 \\
\hline
\end{tabular}

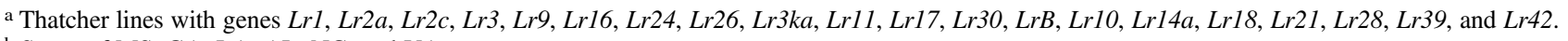

b States of MS, GA, LA, AL, NC, and VA.

c State of NY.

d States of MO, IN, KY, OH, and IL.

e States of TX and OK.

${ }^{\mathrm{f}} \mathrm{States}$ of KS and NE.

S States of MN, SD, and ND.

${ }^{\mathrm{h}}$ State of CA.

${ }^{\mathrm{i}}$ States of ID and WA. 
Table 1. (Continued from previous page)

\begin{tabular}{|c|c|c|c|c|c|c|c|c|c|c|c|c|c|c|c|c|c|c|}
\hline \multirow{2}{*}{$\begin{array}{l}\text { Phenotype } \\
\text { virulence }\end{array}$} & \multicolumn{2}{|c|}{ Area $1^{b}$} & \multicolumn{2}{|c|}{ Area $2^{c}$} & \multicolumn{2}{|c|}{ Area $3^{d}$} & \multicolumn{2}{|c|}{ Area $4^{e}$} & \multicolumn{2}{|c|}{ Area $5^{f}$} & \multicolumn{2}{|c|}{ Area 69 } & \multicolumn{2}{|c|}{ Area $7^{\text {h }}$} & \multicolumn{2}{|c|}{ Area $8^{\mathbf{i}}$} & \multicolumn{2}{|c|}{ Total } \\
\hline & $\#$ & $\%$ & $\#$ & $\%$ & $\#$ & $\%$ & $\#$ & $\%$ & $\#$ & $\%$ & $\#$ & $\%$ & $\#$ & $\%$ & $\#$ & $\%$ & $\#$ & $\%$ \\
\hline $\begin{array}{l}\text { PBDGG } \\
1,2 \mathrm{c}, 3,17,10,28\end{array}$ & 0 & 0 & 3 & 100 & 0 & 0 & 0 & 0 & 0 & 0 & 0 & 0 & 0 & 0 & 0 & 0 & 3 & 0.6 \\
\hline $\begin{array}{l}\text { PBDGJ } \\
1,2 \mathrm{c}, 3,17,10,28,39\end{array}$ & 0 & 0 & 0 & 0 & 0 & 0 & 0 & 0 & 0 & 0 & 3 & 2.4 & 0 & 0 & 0 & 0 & 3 & 0.6 \\
\hline $\begin{array}{l}\text { PBDJG } \\
1,2 \mathrm{c}, 3,17,10,14 \mathrm{a}, 28\end{array}$ & 0 & 0 & 0 & 0 & 0 & 0 & 0 & 0 & 0 & 0 & 0 & 0 & 0 & 0 & 1 & 4.5 & 1 & 0.2 \\
\hline $\begin{array}{l}\text { TBBGJ } \\
1,2 \mathrm{a}, 2 \mathrm{c}, 3,10,28,39\end{array}$ & 0 & 0 & 0 & 0 & 0 & 0 & 0 & 0 & 0 & 0 & 1 & 0.8 & 0 & 0 & 0 & 0 & 1 & 0.2 \\
\hline $\begin{array}{l}\text { TBBGS } \\
1,2 \mathrm{a}, 2 \mathrm{c}, 3,10,21,28,39\end{array}$ & 0 & 0 & 0 & 0 & 0 & 0 & 7 & 6 & 4 & 10 & 17 & 13.4 & 0 & 0 & 0 & 0 & 28 & 6.0 \\
\hline $\begin{array}{l}\text { TBBKG } \\
1,2 \mathrm{a}, 2 \mathrm{c}, 3,10,14 \mathrm{a}, 18,28\end{array}$ & 0 & 0 & 0 & 0 & 2 & 5.3 & 0 & 0 & 0 & 0 & 0 & 0 & 0 & 0 & 0 & 0 & 2 & 0.4 \\
\hline $\begin{array}{l}\text { TBBQJ } \\
1,2 \mathrm{a}, 2 \mathrm{c}, 3, \mathrm{~B}, 10,28,39\end{array}$ & 0 & 0 & 0 & 0 & 0 & 0 & 0 & 0 & 0 & 0 & 1 & 0.8 & 0 & 0 & 0 & 0 & 1 & 0.2 \\
\hline $\begin{array}{l}\text { TBGJG } \\
1,2 \mathrm{a}, 2 \mathrm{c}, 3,11,10,14 \mathrm{a}, 28\end{array}$ & 0 & 0 & 0 & 0 & 1 & 2.6 & 0 & 0 & 0 & 0 & 0 & 0 & 0 & 0 & 0 & 0 & 1 & 0.2 \\
\hline $\begin{array}{l}\text { TBRKG } \\
1,2 \mathrm{a}, 2 \mathrm{c}, 3,3 \mathrm{ka}, 11,30,10,14 \mathrm{a}, 18,28\end{array}$ & 7 & 5.8 & 0 & 0 & 1 & 2.6 & 1 & 0.9 & 0 & 0 & 0 & 0 & 0 & 0 & 0 & 0 & 9 & 1.9 \\
\hline $\begin{array}{l}\text { TCGJG } \\
1,2 \mathrm{a}, 2 \mathrm{c}, 3,26,11,10,14 \mathrm{a}, 28\end{array}$ & 0 & 0 & 0 & 0 & 1 & 2.6 & 0 & 0 & 0 & 0 & 0 & 0 & 0 & 0 & 0 & 0 & 1 & 0.2 \\
\hline $\begin{array}{l}\text { TCGKG } \\
1,2 \mathrm{a}, 2 \mathrm{c}, 3,26,11,10,14 \mathrm{a}, 18,28\end{array}$ & 1 & 0.8 & 0 & 0 & 0 & 0 & 0 & 0 & 0 & 0 & 0 & 0 & 0 & 0 & 0 & 0 & 1 & 0.2 \\
\hline $\begin{array}{l}\text { TCJSB } \\
1,2 \mathrm{a}, 2 \mathrm{c}, 3,26,11,17, \mathrm{~B}, 10,14 \mathrm{a}\end{array}$ & 2 & 1.7 & 0 & 0 & 0 & 0 & 0 & 0 & 0 & 0 & 0 & 0 & 0 & 0 & 0 & 0 & 2 & 0.4 \\
\hline $\begin{array}{l}\text { TCJTB } \\
1,2 \mathrm{a}, 2 \mathrm{c}, 3,26,11,17, \mathrm{~B}, 10,14 \mathrm{a}, 18\end{array}$ & 2 & 1.7 & 0 & 0 & 0 & 0 & 0 & 0 & 0 & 0 & 0 & 0 & 0 & 0 & 0 & 0 & 2 & 0.4 \\
\hline $\begin{array}{l}\text { TCRFG } \\
1,2 \mathrm{a}, 2 \mathrm{c}, 3,26,3 \mathrm{ka}, 11,30,14 \mathrm{a}, 18,28\end{array}$ & 0 & 0 & 0 & 0 & 0 & 0 & 0 & 0 & 0 & 0 & 1 & 0.8 & 0 & 0 & 0 & 0 & 1 & 0.2 \\
\hline $\begin{array}{l}\text { TCRKG } \\
1,2 \mathrm{a}, 2 \mathrm{c}, 3,26,3 \mathrm{ka}, 11,30,10,14 \mathrm{a}, 18,28\end{array}$ & 4 & 3.3 & 0 & 0 & 0 & 0 & 0 & 0 & 1 & 2.5 & 4 & 3.1 & 0 & 0 & 0 & 0 & 9 & 1.9 \\
\hline $\begin{array}{l}\text { TCSQB } \\
1,2 \mathrm{a}, 2 \mathrm{c}, 3,26,3 \mathrm{ka}, 11,17, \mathrm{~B}, 10\end{array}$ & 3 & 2.5 & 0 & 0 & 0 & 0 & 0 & 0 & 0 & 0 & 0 & 0 & 0 & 0 & 0 & 0 & 3 & 0.6 \\
\hline $\begin{array}{l}\text { TCTNB } \\
1,2 \mathrm{a}, 2 \mathrm{c}, 3,26,3 \mathrm{ka}, 11,17,30, \mathrm{~B}, 14 \mathrm{a}\end{array}$ & 5 & 4.2 & 0 & 0 & 0 & 0 & 0 & 0 & 0 & 0 & 0 & 0 & 0 & 0 & 0 & 0 & 5 & 1.1 \\
\hline $\begin{array}{l}\text { TCTSB } \\
1,2 \mathrm{a}, 2 \mathrm{c}, 3,26,3 \mathrm{ka}, 11,17,30, \mathrm{~B}, 10,14 \mathrm{a}\end{array}$ & 1 & 0.8 & 0 & 0 & 1 & 2.6 & 0 & 0 & 0 & 0 & 0 & 0 & 0 & 0 & 0 & 0 & 2 & 0.4 \\
\hline $\begin{array}{l}\text { TDBGD } \\
1,2 \mathrm{a}, 2 \mathrm{c}, 3,24,10,39\end{array}$ & 0 & 0 & 0 & 0 & 0 & 0 & 0 & 0 & 1 & 2.5 & 0 & 0 & 0 & 0 & 0 & 0 & 1 & 0.2 \\
\hline $\begin{array}{l}\text { TDPSB } \\
1,2 \mathrm{a}, 2 \mathrm{c}, 3,24,3 \mathrm{ka}, 17,30, \mathrm{~B}, 10,14 \mathrm{a}\end{array}$ & 0 & 0 & 0 & 0 & 1 & 0.9 & 0 & 0 & 0 & 0 & 0 & 0 & 0 & 0 & 0 & 0 & 2 & 0.4 \\
\hline $\begin{array}{l}\text { TDRKG } \\
1,2 \mathrm{a}, 2 \mathrm{c}, 3,24,3 \mathrm{ka}, 11,30,10,14 \mathrm{a}, 18,28\end{array}$ & 0 & 0 & 0 & 0 & 0 & 1 & 0.9 & 0 & 0 & 0 & 0 & 0 & 0 & 0 & 0 & 0 & 1 & 0.2 \\
\hline $\begin{array}{l}\text { TDTSB } \\
1,2 \mathrm{a}, 2 \mathrm{c}, 3,24,3 \mathrm{ka}, 11,17,30, \mathrm{~B}, 10,14 \mathrm{a}\end{array}$ & 0 & 0 & 0 & 0 & 1 & 2.6 & 0 & 0 & 0 & 0 & 0 & 0 & 0 & 0 & 0 & 0 & 1 & 0.2 \\
\hline $\begin{array}{l}\text { TFBJQ } \\
1,2 \mathrm{a}, 2 \mathrm{c}, 3,24,26,10,14 \mathrm{a}, 21,28\end{array}$ & 0 & 0 & 0 & 0 & 0 & 0 & 0 & 0 & 1 & 2.5 & 2 & 1.6 & 0 & 0 & 0 & 0 & 3 & 0.6 \\
\hline $\begin{array}{l}\text { TFPSB } \\
1,2 \mathrm{a}, 2 \mathrm{c}, 3,24,26,3 \mathrm{ka}, 17,30, \mathrm{~B}, 10,14 \mathrm{a}\end{array}$ & 0 & 0 & 0 & 0 & 0 & 0 & 0 & 0 & 0 & 0 & 3 & 2.4 & 0 & 0 & 0 & 0 & 3 & 0.6 \\
\hline $\begin{array}{l}\text { TFTNB } \\
1,2 \mathrm{a}, 2 \mathrm{c}, 3,24,26,3 \mathrm{ka}, 11,17,30, \mathrm{~B}, 14 \mathrm{a}\end{array}$ & 0 & 0 & 0 & 0 & 1 & 2.6 & 0 & 0 & 0 & 0 & 0 & 0 & 0 & 0 & 0 & 0 & 1 & 0.2 \\
\hline $\begin{array}{l}\text { TFTSB } \\
1,2 \mathrm{a}, 2 \mathrm{c}, 3,24,26,3 \mathrm{ka}, 11,17,30, \mathrm{~B}, 10,14 \mathrm{a}\end{array}$ & 1 & 0.8 & 0 & 0 & 3 & 7.9 & 43 & 36.7 & 0 & 0 & 4 & 3.1 & 0 & 0 & 0 & 0 & 51 & 10.9 \\
\hline $\begin{array}{l}\text { TNBGJ } \\
1,2 \mathrm{a}, 2 \mathrm{c}, 3,9,24,10,28,39\end{array}$ & 0 & 0 & 0 & 0 & 0 & 0 & 6 & 5.1 & 5 & 12.5 & 12 & 9.4 & 0 & 0 & 0 & 0 & 23 & 4.9 \\
\hline $\begin{array}{l}\text { TNBJJ } \\
1,2 \mathrm{a}, 2 \mathrm{c}, 3,9,24,10,14 \mathrm{a}, 28,39\end{array}$ & 1 & 0.8 & 0 & 0 & 0 & 0 & 4 & 3.4 & 2 & 5 & 20 & 15.7 & 0 & 0 & 0 & 0 & 27 & 5.8 \\
\hline $\begin{array}{l}\text { TNMJJ } \\
1,2 \mathrm{a}, 2 \mathrm{c}, 3,9,24,3 \mathrm{ka}, 30,10,14 \mathrm{a}, 28,39\end{array}$ & 0 & 0 & 0 & 0 & 0 & 0 & 0 & 0 & 0 & 0 & 1 & 0.8 & 0 & 0 & 0 & 0 & 1 & 0.2 \\
\hline $\begin{array}{l}\text { TNPSD } \\
1,2 \mathrm{a}, 2 \mathrm{c}, 3,9,24,3 \mathrm{ka}, 17,30, \mathrm{~B}, 10,14 \mathrm{a}, 39\end{array}$ & 0 & 0 & 0 & 0 & 0 & 0 & 1 & 0.9 & 0 & 0 & 0 & 0 & 0 & 0 & 0 & 0 & 1 & 0.2 \\
\hline $\begin{array}{l}\text { TNRJJ } \\
1,2 \mathrm{a}, 2 \mathrm{c}, 3,9,24,3 \mathrm{ka}, 11,30,10,14 \mathrm{a}, 28,39\end{array}$ & 4 & 3.3 & 0 & 0 & 0 & 0 & 1 & 0.9 & 0 & 0 & 0 & 0 & 0 & 0 & 0 & 0 & 5 & 1.1 \\
\hline $\begin{array}{l}\text { TPBGJ } \\
1,2 \mathrm{a}, 2 \mathrm{c}, 3,9,24,26,10,28,39\end{array}$ & 0 & 0 & 0 & 0 & 0 & 0 & 0 & 0 & 0 & 0 & 4 & 3.1 & 0 & 0 & 0 & 0 & 4 & 0.9 \\
\hline $\begin{array}{l}\text { TPBJJ } \\
1,2 \mathrm{a}, 2 \mathrm{c}, 3,9,24,26,10,14 \mathrm{a}, 28,39\end{array}$ & 0 & 0 & 0 & 0 & 0 & 0 & 0 & 0 & 0 & 0 & 2 & 1.6 & 0 & 0 & 0 & 0 & 2 & 0.4 \\
\hline $\begin{array}{l}\text { TPDQJ } \\
1,2 \mathrm{a}, 2 \mathrm{c}, 3,9,24,26,17, \mathrm{~B}, 10,28,39\end{array}$ & 0 & 0 & 0 & 0 & 0 & 0 & 0 & 0 & 0 & 0 & 3 & 2.4 & 0 & 0 & 0 & 0 & 3 & 0.6 \\
\hline Total & 120 & & 3 & & 38 & & 117 & & 40 & & 127 & & 2 & & 22 & & 469 & \\
\hline
\end{tabular}


grown (NASS 2018). Virulence to $L r 21$ was highest in area 6, due to the continued host selection of phenotypes with virulence to $\operatorname{Lr} 21$. Since TBBGS is virulent to both $L r 21$ and $L r 39$, it has virulence to many hard red winter and spring wheat cultivars in the Great Plains region. The winter wheat cultivar 'Bentley' was postulated to have Lr21 and Lr39 (J. Kolmer, unpublished data), and was reported to have high severity of leaf rust in south Texas. Phenotypes with virulence to $L r 21$ are also virulent to $L r 2 a$, which has resulted in a high frequency of virulence to $L r 2 a$ in area 6. Phenotypes TNBJJ and MPPSD, the first and third most common phenotypes in area 6, are virulent to $\operatorname{Lr24}$, which is present in hard red winter cultivars grown in this area, as well as some cultivars in areas 4 and 5 .

In the southeastern states and Ohio Valley region, soft red winter wheat cultivars postulated to have $\operatorname{Lr} 11$ (CK9553, AGS 2056), Lr26

Table 2. Number and frequency (\%) of isolates of Puccinia triticina in the United States in 2017 virulent to $20^{\mathrm{a}}$ lines of wheat with single resistance genes for leaf rust resistance

\begin{tabular}{|c|c|c|c|c|c|c|c|c|c|c|c|c|c|c|c|c|c|c|}
\hline \multirow[b]{2}{*}{ Gene } & \multicolumn{2}{|c|}{ Area $1^{b}$} & \multicolumn{2}{|c|}{ Area $2^{c}$} & \multicolumn{2}{|c|}{ Area $3^{\mathbf{d}}$} & \multicolumn{2}{|c|}{ Area $4^{e}$} & \multicolumn{2}{|c|}{ Area $5^{f}$} & \multicolumn{2}{|c|}{ Area $6^{g}$} & \multicolumn{2}{|c|}{ Area $7^{\mathrm{h}}$} & \multicolumn{2}{|c|}{ Area $8^{i}$} & \multicolumn{2}{|c|}{ Total } \\
\hline & $\#$ & $\%$ & $\#$ & $\%$ & $\#$ & $\%$ & $\#$ & $\%$ & $\#$ & $\%$ & $\#$ & $\%$ & $\#$ & $\%$ & $\#$ & $\%$ & $\#$ & $\%$ \\
\hline Lrl & 120 & 100 & 3 & 100 & 38 & 100 & 117 & 100 & 40 & 100 & 127 & 100 & 2 & 100 & 22 & 100 & 469 & 100 \\
\hline$L r 2 a$ & 31 & 25.8 & 0 & 0 & 12 & 31.6 & 65 & 55.6 & 14 & 35.0 & 75 & 59.1 & 0 & 0 & 0 & 0 & 197 & 42 \\
\hline$L r 2 c$ & 31 & 25.8 & 3 & 100 & 12 & 31.6 & 65 & 55.6 & 14 & 35.0 & 78 & 61.4 & 0 & 0 & 1 & 4.5 & 204 & 43.5 \\
\hline$L r 3$ & 119 & 99.2 & 3 & 100 & 38 & 100 & 117 & 100 & 40 & 100 & 127 & 100 & 2 & 100 & 9 & 40.9 & 455 & 97 \\
\hline $\operatorname{Lr} 9$ & 18 & 15 & 0 & 0 & 1 & 2.6 & 41 & 35 & 21 & 52.5 & 67 & 52.8 & 0 & 0 & 0 & 0 & 148 & 31.6 \\
\hline Lr16 & 0 & 0 & 0 & 0 & 0 & 0 & 0 & 0 & 0 & 0 & 1 & 0.8 & 0 & 0 & 0 & 0 & 1 & 0.2 \\
\hline$L r 24$ & 24 & 20.0 & 0 & 0 & 8 & 21.1 & 86 & 73.5 & 22 & 55.0 & 80 & 63.0 & 0 & 0 & 0 & 0 & 220 & 46.9 \\
\hline $\operatorname{Lr} 26$ & 55 & 45.8 & 0 & 0 & 15 & 39.5 & 68 & 58.1 & 11 & 27.5 & 46 & 36.2 & 1 & 50 & 9 & 40.9 & 205 & 43.7 \\
\hline Lr3ka & 102 & 85 & 0 & 0 & 34 & 89.5 & 88 & 75.2 & 19 & 47.5 & 50 & 39.4 & 0 & 0 & 0 & 0 & 293 & 62.5 \\
\hline Lr11 & 92 & 76.7 & 0 & 0 & 33 & 86.8 & 46 & 39.3 & 5 & 12.5 & 15 & 11.8 & 0 & 0 & 0 & 0 & 191 & 40.7 \\
\hline Lr17 & 98 & 81.7 & 3 & 100 & 33 & 86.8 & 96 & 82.1 & 25 & 62.5 & 61 & 48.0 & 2 & 100 & 22 & 100 & 340 & 72.5 \\
\hline Lr30 & 98 & 81.7 & 0 & 0 & 34 & 89.5 & 88 & 75.2 & 19 & 47.5 & 50 & 39.4 & 0 & 0 & 0 & 0 & 289 & 61.6 \\
\hline$L r B$ & 98 & 81.7 & 0 & 0 & 33 & 86.8 & 96 & 82.1 & 25 & 62.5 & 59 & 46.5 & 2 & 100 & 21 & 95.5 & 334 & 71.2 \\
\hline Lr10 & 58 & 48.3 & 3 & 100 & 13 & 34.2 & 116 & 99.1 & 37 & 92.5 & 124 & 97.6 & 2 & 100 & 22 & 100 & 375 & 80 \\
\hline Lr14a & 117 & 97.5 & 0 & 0 & 38 & 100 & 103 & 88.0 & 30 & 75.0 & 86 & 67.7 & 2 & 100 & 22 & 100 & 398 & 84.9 \\
\hline Lr18 & 15 & 12.5 & 0 & 0 & 3 & 7.9 & 2 & 1.7 & 1 & 2.5 & 5 & 3.9 & 0 & 0 & 0 & 0 & 26 & 5.5 \\
\hline$L r 21$ & 0 & 0 & 0 & 0 & 0 & 0 & 7 & 6.0 & 5 & 12.5 & 19 & 15.0 & 0 & 0 & 0 & 0 & 31 & 6.6 \\
\hline $\operatorname{Lr} 28$ & 23 & 19.2 & 3 & 100 & 5 & 13.2 & 21 & 17.9 & 14 & 35.0 & 75 & 59.1 & 0 & 0 & 22 & 100 & 163 & 34.8 \\
\hline Lr39 & 30 & 25.0 & 0 & 0 & 2 & 5.3 & 60 & 51.3 & 35 & 87.5 & 102 & 80.3 & 2 & 100 & 0 & 0 & 231 & 49.3 \\
\hline Lr42 & 0 & 0 & 0 & 0 & 0 & 0 & 0 & 0 & 0 & 0 & 0 & 0 & 0 & 0 & 0 & 0 & 0 & 0 \\
\hline
\end{tabular}

a Thatcher lines with genes Lr1, Lr2a, Lr2c, Lr3, Lr9, Lr16, Lr24, Lr26, Lr3ka, Lr11, Lr17, Lr30, LrB, Lr10, Lr14a, Lr18, Lr21, Lr28, Lr39, and Lr42.

${ }^{\mathrm{b}}$ States of MS, GA, LA, AL, NC, and VA.

${ }^{c}$ State of NY.

d States of MO, KY, IN, OH, and IL.

e States of TX and OK.

${ }^{\mathrm{f}} \mathrm{States}$ of KS and NE.

${ }^{\mathrm{g}}$ States of MN, ND, and SD.

${ }^{\mathrm{h}}$ State of CA.

${ }^{\mathrm{i}}$ States of ID and WA.
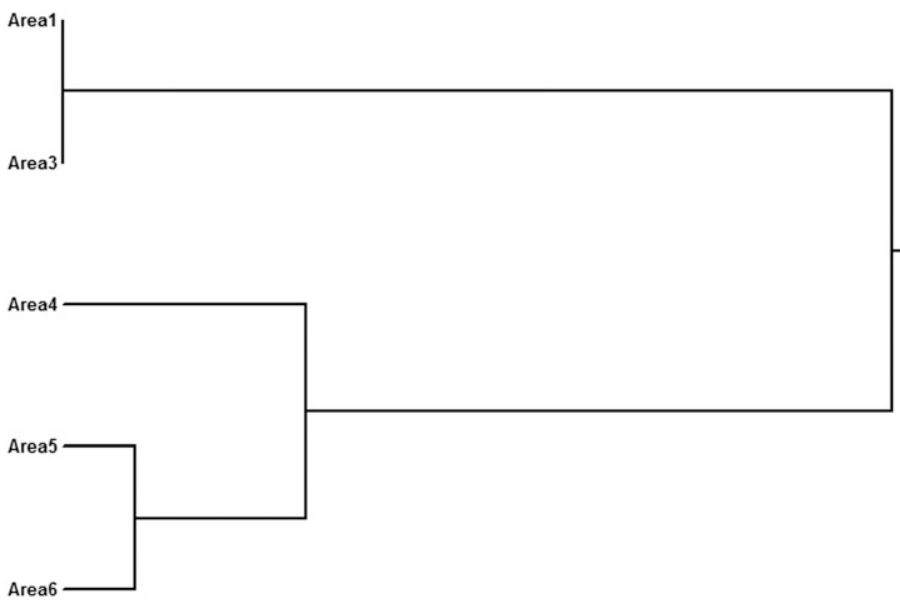

Area

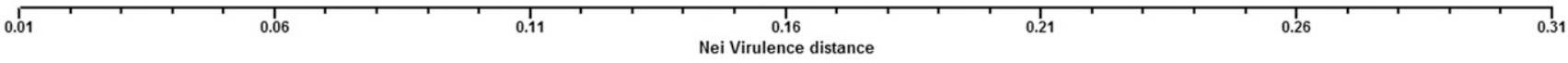

Fig. 2. UPGMA dendrogram of Nei's genetic distance adapted for virulence of Puccinia triticina isolates in areas 1, 3, 4, 5, 6, and 8 in the United States in 2017. 
(AGS 2000, Arcadia), and Lr18 (Jamestown, Hilliard) (J. Kolmer, unpublished data) are grown. Virulence to Lrll and Lrl8 was highest in areas 1 and 3, due to selection of phenotypes with virulence to these genes. Virulence to $L r 26$ is common in areas 1,3, 4, 5, and 6, due to its presence in hard red winter and soft red winter wheat cultivars. The three most common phenotypes in areas 1 and 3, MBTNB, MCTNB, and TCRKG, where soft red winter wheat cultivars are grown, are virulent to $L r 11$, and vary for virulence to $L r 18$ and Lr26. In 2016 (Kolmer and Hughes 2018), phenotypes MBTNB (17.7\%), MBDSD (13.7\%), and TNBJJ (7.1\%) were the three most common phenotypes across the United States. MBTNB was still the most common phenotype in 2017; however, MBDSD and TNBJJ occurred at lower frequencies in 2017.

Some unusual $P$. triticina phenotypes were detected for the first time in 2017. Phenotypes LBDSG and LCDSG were the only phenotypes that were avirulent to $L r 3$. These two phenotypes had intermediate IT of small to moderate uredinia with prominent chlorosis to $L r 3$. Most other phenotypes that are avirulent to $L r 3$ produce a very low IT of hypersensitive flecks with minute uredinia (McIntosh et al. 1995). Phenotypes LBDSG and LCDSG were found almost exclusively in Washington, with a single isolate of LCDSG found in area 1. Another unusual phenotype, MCDSG, found only in Washington, has similar virulence to LBDSG and LCDSG, except for virulence to $L r 3$. All three phenotypes are virulent to $L r 17$ and $L r 28$ and avirulent to $L r 2 a$. Since the mid-1990s, almost all phenotypes that are avirulent to $L r 2 a$ and virulent to $L r 17$ have been avirulent to $L r 28$. The absence of these phenotypes in the Great Plains and soft red winter wheat regions suggests that there is limited migration of $P$. triticina between Washington and the other regions in the United States. Isolates with phenotypes PBDGJ, PBDJG, and PBDGG were collected mostly from triticale in 2017. These phenotypes are unique compared with the $\mathrm{M}$ - or $\mathrm{T}$ - phenotypes since they are avirulent to $L r 2 a$ and virulent to $L r 2 c$ and $L r 17$. These phenotypes were also detected in 2016, mostly from triticale. Since no other virulence phenotypes were found on triticale, these phenotypes may be specifically adapted to this host.

In the last 30 years, the population of $P$. triticina in the United States has been shaped by the presence of leaf rust resistance genes in the different regional wheat classes, the clonal reproduction of urediniospores, migration of virulence phenotypes across regions, and the introduction of new genotypes. The first hard red winter wheat cultivars with leaf rust resistance were released in the mid-1940s (Browder 1973, 1980). Since then, a number of leaf rust resistance genes that confer resistance to specific virulence phenotypes, many from lower ploidy relatives of wheat, have been deployed in winter and spring wheat cultivars. However, all of these genes, regardless of origin, have selected virulent phenotypes of $P$. triticina, rendering the resistance less effective. The presence of different resistance genes in the different market classes of wheat has resulted in long-standing regional populations of $P$. triticina virulence phenotypes in the United States. The clonal reproduction of urediniospores enables the widespread dissemination of virulence phenotypes across and between regions. Phenotypes selected by host resistance genes in the southeastern states or southern Great Plains can migrate by windblown urediniospores to states in the Ohio Valley area and to the northern spring wheat region of Minnesota. In the absence of any sexual recombination in $P$. triticina in the United States, virulence to specific resistance genes is effectively linked. Phenotypes selected by virulence to one particular resistance gene can also have virulence to other resistance genes, even though these genes may not be present in the host population. The distinct molecular genotype and virulence groups of $P$. triticina may have resulted from different introductions of leaf rust to North America during the establishment of wheat agriculture. New genotypes of $P$. triticina have been introduced to the United States and Canada in the last 20 years (Kolmer 2001), and their descendants have become predominant in the current population.

Long-lasting leaf rust resistance in winter and spring wheat cultivars in the United States has been difficult to achieve given the ability of $P$. triticina populations to quickly adapt to new resistance genes in wheat (Kolmer et al. 2009). However, hard winter cultivars such as 'Duster' and 'Santa Fe' with combinations of the adult plant resistance genes $L r 34, L r 46$, and $L r 77$ have had long-lasting resistance in the Great Plains region (Kolmer 2017; Kolmer et al. 2018b, 2019). The soft red winter wheat cultivars 'Caldwell' (Kolmer et al. 2018a) and 'Clark' (Li et al. 2017) that have an adult plant resistance gene that may be $L r 74$ have had a moderate level of leaf rust resistance for some years. Spring wheat cultivars such as 'Norm' and 'Alsen' (Oelke and Kolmer 2005), with combinations of the seedling genes Lr16 and Lr23, in various combinations with $L r 13$ and $L r 34$, have had good resistance over time in the northern Great Plains. In contrast, cultivars with only a single phenotype-specific seedling resistance gene such as 'Jagger' with Lr37, 'Overley' with Lr39, and 'Faller' with Lr21 have had very short-lived resistance due to the rapid increase of phenotypes with virulence to all of these genes. Future efforts should concentrate on increasing the frequency of adult plant resistance genes in wheat germplasm pools by use of diagnostic markers combined with phenotypic selection, and developing cultivars with combinations of effective seedling and adult plant resistance genes.

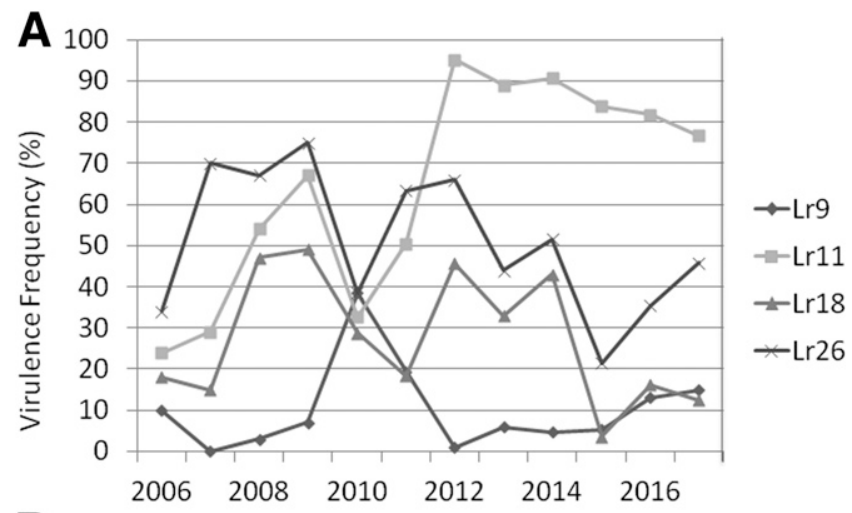

B

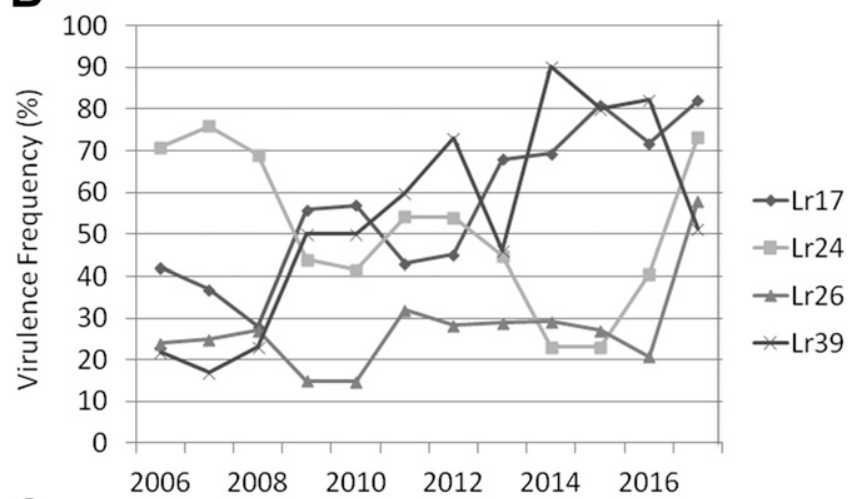

C

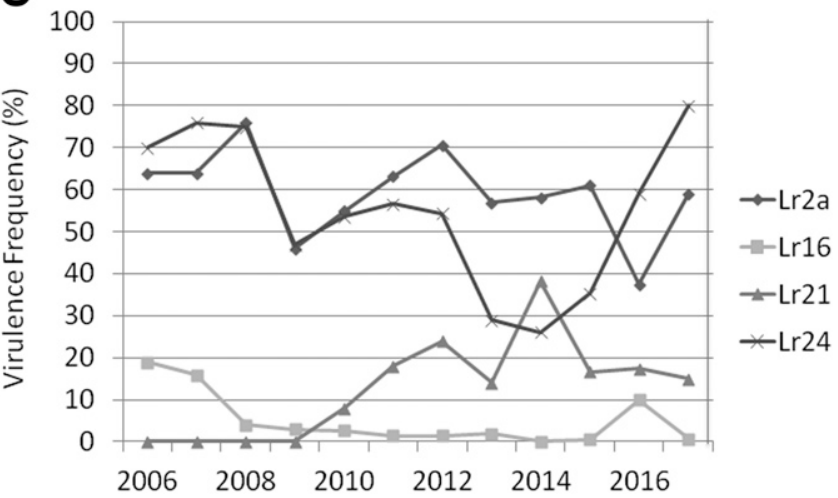

Fig. 3. Frequency (\%) of Puccinia triticina isolates with virulence to selected leaf rust resistance genes from 2005 to 2017 in the following areas of the United States: southeastern states (A, Area 1); southern Great Plains (B, Area 4); and northern Great Plains (C, Area 6). 


\section{Literature Cited}

Browder, L. E. 1973. Probable genotype of some Triticum aestivum agent derivatives for reaction to Puccinia recondita f. sp. tritici. Crop Sci. 13:203-206.

Browder, L. E. 1980. A compendium of information about named genes for low reaction to Puccinia recondita in wheat. Crop Sci. 20:775-779.

Browder, L. E., Roelfs, A. P., and Johnston, C. O. 1965. Physiologic specialization of Puccinia recondita Rob. ex Desm. f. sp. tritici in the United States in 1962 and 1963. U.S. Agric. Res. Serv. ARS 34-69.

Cruz, C. D., Peterson, G. L., Bockus, W. W., Kankanala, P., Dubcovsky, J., Jordan, K. W., Ahkunov, E., Chumley, F., Baldelomar, F. D., and Valent, B. 2016. The 2NS translocation from Aegilops ventricosa confers resistance to the Triticum pathotype of Magnaporthe oryzae. Crop Sci. 56:990-1000.

Dyck, P. L., and Samborski, D. J. 1974. Inheritance of virulence in Puccinia recondita on alleles at the $L r 2$ locus for resistance in wheat. Can. J. Genet. Cytol. 16:323-332.

Johnston, C. O., Caldwell, R. M., Compton, L. E., and Browder, L. E. 1968. Physiologic races of Puccinia recondita f. sp. tritici in the United States From 1926 through 1960. USDA Tech. Bull. 1393:1-18.

Kolmer, J., and Anderson, J. A. 2011. First detection in North America of virulence in wheat leaf rust (Puccinia triticina) to seedling plants of wheat with $\operatorname{Lr} 21$. Plant Dis. 95:1032.

Kolmer, J., Chen, X., and Jin, Y. 2009. Diseases which challenge global wheat production - the wheat rusts. Ch. 5 in: Wheat: Science and Trade. B. F. Carver, ed. Wiley-Blackwell, Ames, IA.

Kolmer, J. A. 1998. Physiologic specialization of Puccinia recondita f. sp. tritici in Canada in 1996. Can. J. Plant Pathol. 20:176-181.

Kolmer, J. A. 2001. Molecular polymorphism and virulence phenotypes of the wheat leaf rust fungus Puccinia triticina in Canada. Can. J. Bot. 79:917-926.

Kolmer, J. A. 2003. Postulation of leaf rust resistance genes in selected soft red winter wheats. Crop Sci. 43:1266-1274.

Kolmer, J. A. 2010. Genetics of leaf rust resistance in the soft red winter wheat cultivars Coker 9663 and Pioneer 26R61. Plant Dis. 94:628-632.

Kolmer, J. A. 2017. Genetics of leaf rust resistance in the hard red winter wheat cultivars Santa Fe and Duster. Crop Sci. 57:2500-2505.

Kolmer, J. A., Chao, S., Brown-Guedira, G., Bansal, U., and Bariana, H. 2018a. Adult plant leaf rust resistance derived from the soft red winter wheat cultivar 'Caldwell' maps to chromosome 3BS. Crop Sci. 58:152-158.

Kolmer, J. A., and Hughes, M. E. 2018. Physiologic specialization of Puccinia triticina on wheat in the United States in 2016. Plant Dis. 102:1066-1071.

Kolmer, J. A., Jin, Y., and Long, D. L. 2007a. Wheat leaf and stem rust in the United States. Aust. J. Agric. Res. 58:631-638.

Kolmer, J. A., Long, D. L., and Hughes, M. E. 2005. Physiological specialization of Puccinia triticina on wheat in the United States in 2003. Plant Dis. 89: 1201-1206.
Kolmer, J. A., Long, D. L., and Hughes, M. E. 2007b. Physiological specialization of Puccinia triticina on wheat in the United States in 2005. Plant Dis. 91: 979-984.

Kolmer, J. A., Su, Z., Bernardo, A., Bai, G., and Chao, S. 2018b. Mapping and characterization of the new adult plant leaf rust resistance gene $\operatorname{Lr} 77$ derived from Santa Fe winter wheat. Theor. Appl. Genet. 131:1553-1560.

Kolmer, J. A., Su, Z., Bernardo, A., and Chao, S. 2019. A backcross line of Thatcher wheat with adult plant resistance leaf rust resistance derived from Duster wheat has Lr46 and Lr77. Phytopathology 109:127-132.

Li, C., Wang, Z., Li, C., Bowden, R., Bai, G., Li, C., Li, C., Su, Z., and Carver B. F. 2017. Mapping of quantitative trait loci for leaf rust resistance in the wheat population Ning7840 $\times$ Clark. Plant Dis. 101:1974-1979.

Long, D. L., and Kolmer, J. A. 1989. A North American system of nomenclature for Puccinia recondita f.sp. tritici. Phytopathology 79:525-529.

Long, D. L., Leonard, K. J., and Hughes, M. E. 2000. Virulence of Puccinia triticina on wheat in the United States from 1996 to 1998. Plant Dis. 84: 1334-1341.

Long, D. L., Schafer, J. F., and Roelfs, A. P. 1985. Specific virulence of Puccinia recondita f. sp. tritici in the United States from 1978 through 1983. Plant Dis. 69:343-347.

Mains, E. B., and Jackson, H. S. 1926. Physiologic specialization in the leaf rust of wheat, Puccinia triticina. Phytopathology 16:89-120.

McIntosh, R. A., Wellings, C. R., and Park, R. F. 1995. Wheat Rusts: An Atlas of Resistance Genes. CSIRO Australia, Kluwer Academic Publishers, Dordrecht.

McVey, D. V., and Long, D. L. 1993. Genes for leaf rust resistance in hard red winter wheat cultivars and parents. Crop Sci. 33:1373-1381.

National Agricultural Statistics Service (NASS). 2018. Statistics by State 2017. https://www.nass.usda.gov/Statistics_by_State. Accessed September 14, 2018

National Oceanic and Atmospheric Administration (NOAA). 2018. National Climate Report 2017. https://www.ncdc.noaa.gov/sotc/national/201713. Accessed September 14, 2018.

Oelke, L. M., and Kolmer, J. A. 2004. Characterization of leaf rust resistance in hard red spring wheat cultivars. Plant Dis. 88:1127-1133.

Oelke, L. M., and Kolmer, J. A. 2005. Genetics of leaf rust resistance in spring wheat cultivars Norm and Alsen. Phytopathology 95:773-778.

Ordoñez, M. E., and Kolmer, J. A. 2009. Differentiation of molecular genotypes and virulence phenotypes of Puccinia triticina from common wheat in North America. Phytopathology 99:750-758.

Roelfs, A. P., Singh, R. P., and Saari, E. E. 1992. Rust Diseases of Wheat: Concepts and Methods of Disease Management. CIMMYT, Mexico.

Xue, S., Kolmer, J. A., Wang, S., and Yan, L. 2018. Mapping of leaf rust resistance genes and molecular characterization of the 2NS/2AS translocation in the wheat cultivar Jagger. G3: Genes, Genomes, Genetics 8:2059-2065. 